\title{
Uro-oncology 2018: new horizons, new treatment options, improved patient outcomes
}

\author{
Ursula M. Vogl (iD
}

Received: 15 February 2018 / Accepted: 16 February 2018 / Published online: 23 February 2018

(C) Springer-Verlag GmbH Austria, part of Springer Nature 2018

The year 2018 is an exciting time to work as a urooncologist. Therapies have developed rapidly in the last year.

The papers collected in this issue of memo review the current standards and future perspectives in urooncology with a focus on prostate, bladder and renal cell cancer, including practice guidelines with a patient case report. This case report reflects the potent drugs that we can offer our metastatic renal cell cancer patients (mRCC) over a very long treatment period including multimodal treatment that leads to an impressive overall survival time with excellent quality of life $[1,2]$.

Prostate Cancer Guidelines [3-6] advise us to hit hard from the very beginning-already in the hormone-sensitive stage of metastatic prostate cancer (mHSPC) with high volume disease. The CHAARTED and STAMPEDE trials emphasized the use of early chemohormonal treatment with six cycles of docetaxel and androgen-deprivation therapy (ADT) [7-9] in the high-volume disease population. Patients with mHSPC, who are not candidates for docetaxel, have another treatment option since the publication of the LATITUDE study [10]. This study showed a benefit for abiraterone plus ADT in mHSPC patients vs ADT in progression-free survival and overall survival. The median time to progression is 36 months, so the costs and the reimbursement of abiraterone will be an upcoming discussion. The costs for docetaxel are relatively low and after 18 weeks, this treatment with manageable and well-known chemotherapy side effects is completed. Abiraterone certainly has less side effects, but we do not know whether there are

\section{U. M. Vogl, MD (ه)}

Department für Onkologie, Barmherzige Schwestern Wien,

Stumpergasse 13, 1060 Vienna, Austria

ursula.vogl@bhs.at any long-term toxicities like cardiac and endocrine complications that these very often multimorbid patients will develop over the long treatment period. And the other question is, whether we should go for the more toxic drug first, when the patient still has a good performance status (PS), and then use abiraterone. Christopher Sweeney citied the musician Eminem in his debate as an advocate for docetaxel at this year's ASCO GU meeting in San Francisco: “One shot-one opportunity". Therefore, we should not miss the option to give docetaxel as a potent drug to our prostate cancer patients during their course of disease. What could be the next step to further improve the outcome? Will we combine chemotherapy, ADT and abiraterone up-front in the future? And most likely enzalutamide will also work in the hormonesensitive setting (ENZAMET trial [11]), but data are not expected before 2020.

MRCC and metastatic bladder cancer (mBC) are tumors where checkpoint inhibition is an important treatment option in 2018. This year we will expect the licensing of ipilimumab and nivolumab as first-line therapy in intermediate- and poor-risk patients with mRCC [12]. Treatment options have been well established in this disease with multiple tyrosine kinase inhibitors. Can we cure these patients with the combination of ipilimumab and nivolumab? Complete remission rates are still low (4\%) and no prognostic markers have been developed so far. Programmed cell death ligand(PDL)-1 expression has not been shown to be a good guidance in selecting patients for checkpoint inhibitors.

In $\mathrm{mBC}$ we have three checkpoint inhibitors available in Europe: pembrolizumab [13, 14] and atezolizumab $[15,16]$ in cisplatin-ineligible patients in first- and second-line after cisplatin failure, nivolumab only as second-line option [17]. The response rate and prognosis improved dramatically with these new 
agents. The second-line options with taxanes [18] or vinflunine [19] were limited with low response rates. Moreover, most patients' PS did not allow to apply further treatment. In 2018 we have treatment options to offer for the frail and cisplatin-ineligible patients with PDL-1 and PD-1 inhibitors.

Immuno-oncology plays an important role in urooncology, since especially $\mathrm{mBC}$ and $\mathrm{mRCC}$ have a high mutational burden [20].

I am proud to work as an uro-oncologist in this exciting era.

Conflict of interest U.M. Vogl declares that she has no competing interests.

\section{References}

1. Vogl UM, Zehetgruber H, Dominkus M, Hejna M, Zielinski CC, Haitel A, et al. Prognostic factors in metastatic renal cell carcinoma: metastasectomy as independent prognostic variable. BrJCancer. 2006;95(6):691-8.

2. Zaid HB, Parker WP, Safdar NS, Gershman B, Erwin PJ, Murad MH, et al. Outcomes following complete surgical metastasectomy for patients with metastatic renal cell carcinoma: a systematic review and meta-analysis. J Urol. 2017;197(1):44-9.

3. Cornford P, Bellmunt J, Bolla M, Briers E, De SM, Gross T, et al. EAU-ESTRO-SIOG guidelines on prostate cancer. Part II: treatment of relapsing, metastatic, and castration-resistant prostate cancer. Eur Urol. 2017;71(4):630-42.

4. Gillessen S, Attard G, Beer TM, Beltran H, Bossi A, Bristow R, et al. Management of patients with advanced prostate cancer: the report of the advanced prostate cancer consensus conference APCCC 2017. Eur Urol. 2018;73(2):178-211.

5. Mottet N, Bellmunt J, Bolla M, Briers E, Cumberbatch MG, De SM, et al. EAU-ESTRO-SIOG guidelines on prostate cancer. Part 1: screening, diagnosis, and local treatment with curative intent. Eur Urol. 2017;71(4):618-29.

6. Mottet N, De SM, Briers E, Bourke L, Gillessen S, Grummet JP, et al. Updated guidelines for metastatic hormonesensitive prostate cancer: abiraterone acetate combined with castration is another standard. Eur Urol. 2017; https:// doi.org/10.1016/j.eururo.2017.09.029.

7. Gravis G, Boher JM, Joly F, Soulie M, Albiges L, Priou F, et al. Androgen Deprivation Therapy (ADT) plus docetaxel versus $\mathrm{ADT}$ alone in metastatic non castrate prostate cancer: impact of metastatic burden and long-term survival analysis of the randomized phase 3 GETUG-AFU15 trial. Eur Urol. 2016;70(2):256-62.

8. James ND, Sydes MR, Clarke NW, Mason MD, Dearnaley DP, Spears MR, et al. Addition of docetaxel, zoledronic acid, or both to first-line long-term hormone therapy in prostate cancer (STAMPEDE): survival results from an adaptive, multiarm, multistage, platform randomised controlled trial. Lancet. 2016;387(10024):1163-77.

9. Sweeney CJ, Chen YH, Carducci M, Liu G, Jarrard DF, Eisenberger $\mathrm{M}$, et al. Chemohormonal therapy in metastatic hormone-sensitive prostate cancer. N Engl J Med. 2015;373(8):737-46.

10. Fizazi K, Tran N, Fein L, Matsubara N, Rodriguez-Antolin A, Alekseev BY, et al. Abiraterone plus prednisone in metastatic, castration-sensitive prostate cancer. N Engl J Med. 2017;377(4):352-60.

11. Sweeney C, Davis I et al. Enzalutamide in First Line Androgen Deprivation Therapy for Metastatic ProstateCancer (ENZAMET), NCT02446405. 2018.

12. Escudier B, Tannir N, McDermott D. CheckMate 214: efficacy and safety of nivolumab +ipilimumab $(\mathrm{N}+\mathrm{I})$ v sunitinib (S) for treatment-naive advanced or metatstatic renal cell carcinoma (mRCC), including IMDC riskand PDL-1 expression subgroups. 2018.

13. Bellmunt J, Bajorin DF. Pembrolizumab for advanced urothelial carcinoma. NEnglJ Med. 2017;376(23):2304-8.

14. Bellmunt J, de WR, Vaughn DJ, Fradet Y, Lee JL, Fong L, et al. Pembrolizumab as second-line therapy for advanced urothelial carcinoma. NEngl J Med. 2017;376(11):1015-26.

15. Powles T, Duran I, van der Heijden MS, Loriot Y, Vogelzang NJ, De GU, et al. Atezolizumab versus chemotherapy in patients with platinum-treated locally advanced or metastatic urothelial carcinoma (IMvigor211): a multicentre, openlabel, phase 3 randomised controlled trial. Lancet. 2017; https://doi.org/10.1016/S0140-6736(17)33297-X.

16. Rosenberg JE, Hoffman-Censits J, Powles T, van der Heijden MS, Balar AV, Necchi A, et al. Atezolizumab in patients with locally advanced and metastatic urothelial carcinoma who have progressed following treatment with platinum-based chemotherapy: a single-arm, multicentre, phase 2 trial. Lancet. 2016;387(10031):1909-20.

17. Sharma P, Retz M, Siefker-Radtke A, Baron A, Necchi A, BedkeJ, etal. Nivolumabinmetastaticurothelial carcinoma after platinum therapy (CheckMate 275): a multicentre, single-arm, phase 2 trial. Lancet Oncol. 2017;18(3):312-22.

18. Petrylak DP, de Wit R, Chi KN, Drakaki A, Sternberg CN, Nishiyama H, et al. Ramucirumab plus docetaxel versus placebo plus docetaxel in patients with locally advanced or metastatic urothelial carcinoma after platinum-based therapy (RANGE): a randomised, double-blind, phase 3 trial. Lancet. 2017;390(10109):2266-77.

19. Bellmunt J, Theodore C, Demkov T, Komyakov B, Sengelov L, Daugaard G, et al. Phase III trial of vinflunine plus best supportive care compared with best supportive care alone after a platinum-containing regimen in patients with advanced transitional cell carcinoma of the urothelial tract. JClin Oncol. 2009;27(27):4454-61.

20. AlexandrovLB, Nik-ZainalS, Wedge DC, AparicioSA, Behjati $\mathrm{S}$, Biankin AV, et al. Signatures of mutational processes in human cancer. Nature. 2013;500(7463):415-21.

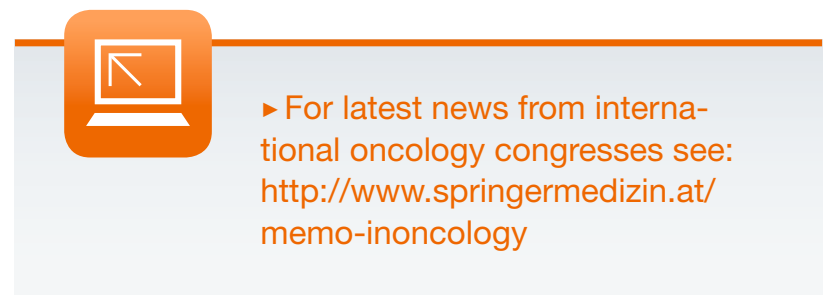

